管释古追節》學

八, 施子陚加約令及以余

ベ行す騂入ス若細厅会

ぷ, 順回材 Nルシ菌從

$\varepsilon$ 一序復料所 $\Rightarrow 2$ 學來 2

九立期 以以れ時, れ

水方遠患温ナテ万号報检ら

, 仙心者室り極患第查獭

三迷器, 十 メ者五法,

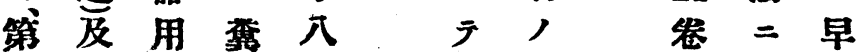

三ビ試便乃短蒦第比期

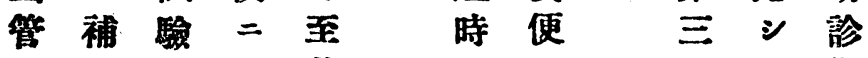

八艋管混廿 間

非卜四合四丙 y 第早法

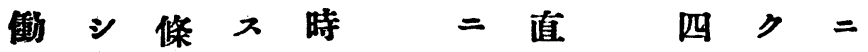

性亏 $\exists$ 間接 號且 就

家健取, れ二盖ッテ

れ

息康 $y 2$ 只同

シ 確 肉

乙家第 れ

免一

万猃 法

万血 管

菌定 $\Rightarrow$

免 清 二

寒 シ 行

疫 ○ 非

天 得 $>$

血 立 働

斜 べ コ

清 或 性

面 シ

우

培之 7

○健 鬼

表㥂

法 = 的

一 康 2

第 8 和

$\exists$

余

四 5

種

管 名 免

\& 此 純

八度

, 方粹

補と血

比面培

$\therefore 2=$

2和試

的 5 臨

与菌管

菌 7 内

菌

䱧 血 清

例， 養

, 清 ○

研 =

- 00

究 要

，診 溶

純 断 菌

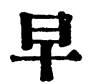

期

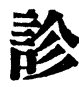

$\Rightarrow$ Ó -

成

粹 シ 現

培得采

斷

入五面

績 ル

養心゙

$\exists \neq$ 同

诸:

第 倍

ᄏ 時

莎 間

以 ב 時

何 二 桸

$=7$

$71=$

市

立

京

都

追

病

汁 院

加

施 7 凝

行 報 笨

七告区

シ 七應

藏

便

E y 7

, 衙 检

十生 查 
便如第 反

性上三㮣

筧, 不晹

二遠 ビ性

依忍第 ナ

り器 互四儿

テ 二管卜 便

異裝八キ便

ナ七混八皇

り顀濁一白

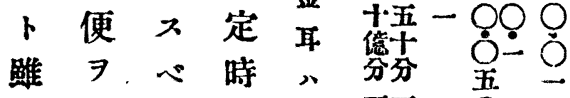

F 沈 三後細一局家家

モ降第娄至菟

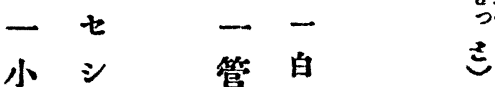

白么八金

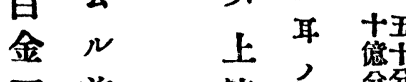

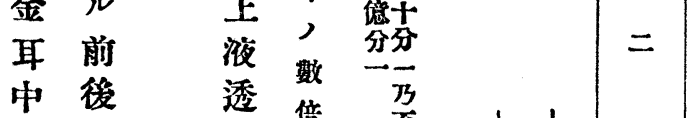

數 =

透倍

百 於

$=$ 相

可

算 菌

シ 數

シ 當

沈 7

降 检

後 入

$=r$

テ

在 $=$

第

》 沈

管

于 降

其 前

至一 11

上 $=$

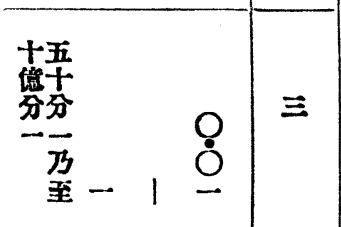

清 在

液 y

八广

八

全 八

凝

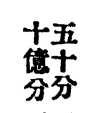

至各培十量

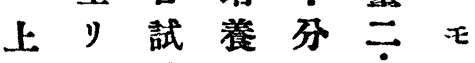
吩之驗 7 - 主へ 順 7 管 以 乃 序三 $\exists+$ 電試 + 年 更七或䠯澛, 水 二度透汾比分 表, 心夕一例的 記温器り白二つ 入室 $=$ 㴗金添 $v=$ 裝時耳加 バ入フノ 7 タ 左 $v=$ 如 加次 $\varepsilon$ ノ一ト》フデん 如定一 - 然各シ 時 時 定 ル管 0 後間時 $⺊=\dot{O}$ 肉二後 $\neq$ 篦食 眼 三肉八便 覧 的 于 眼 各一五 二 粽 的管 白 $\dot{0}$ 菌便二八金結 人成 2 當耳晶 溶分れ初 7 炭 否悉 ら 科》菌・次曹 二沈厂既 テ 達 疑降溶二能三 集 三 否溷》官 区上 7 濁混水 憵液知 シ 合一 , 全ルテシ 0

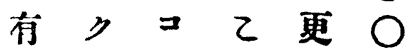
無 清 $⺊$ 亿 $=0$ 马 澄 能 52 O 检、八菌れ妇 查ナズノら スル故純菌 $=$ 二粹五全 
(25)

\begin{tabular}{|c|c|c|c|c|}
\hline 沋 & 藏 & 㼄 & 谷 & \\
\hline
\end{tabular}

第

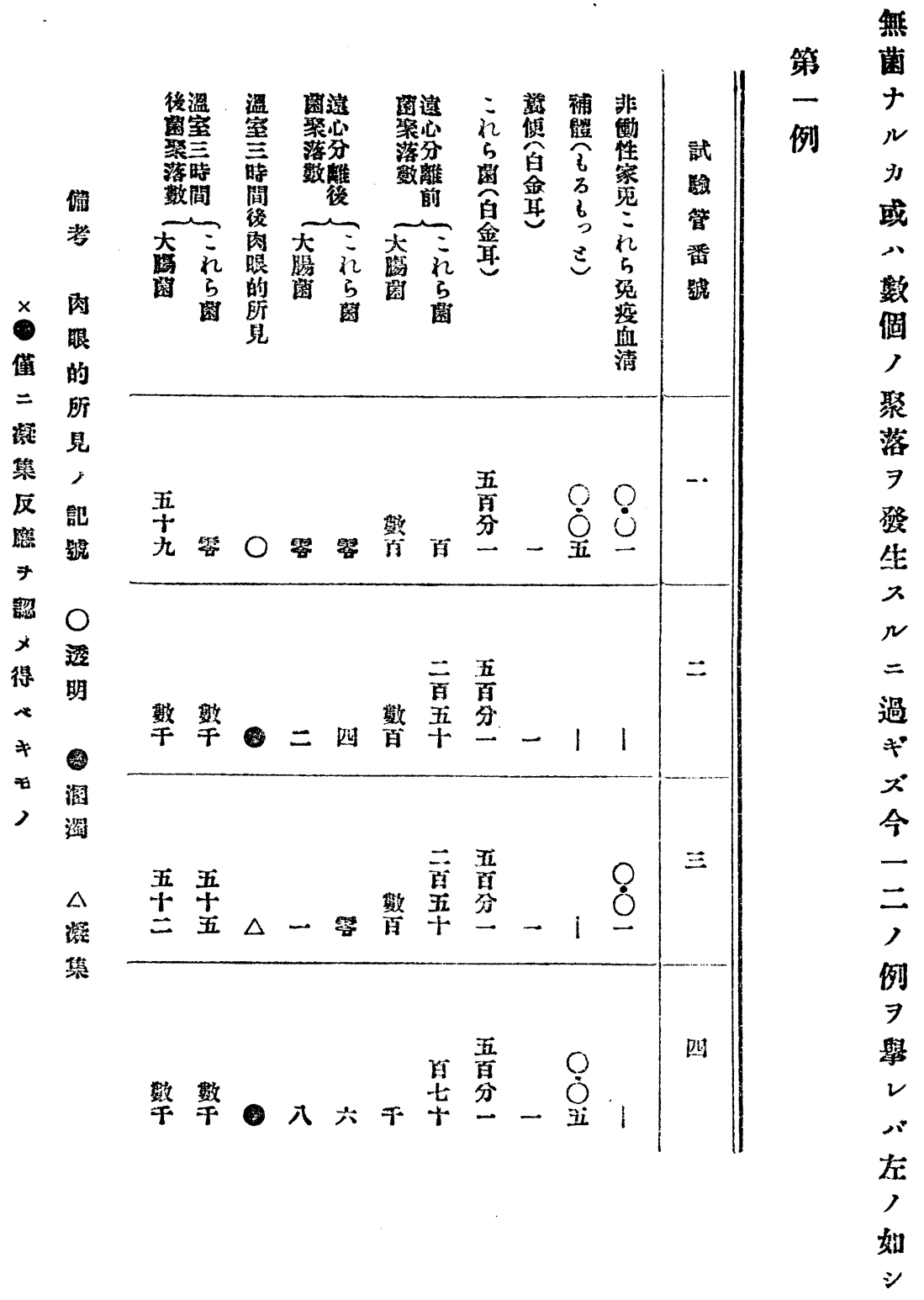

北型点学圈畫铵 
27,

以的是四此

下 5 学時 二

乙菌第間 例

氺 三㣪二

万些及二位

菌少第於 y

量, 四 $\bar{゙}$

五. 障 管 第 明

十躷八一ナ

召 7 溷 管: ル

一蒙渭 小

万ラ 入透如

至ズ 故明ク

十 $=$ = 混

億于 此 シ 和

分其方于

一覒法培机

白疫二飬ら

金血依二菌

耳清儿依量

$\exists=ト リ$ 五.

混依 $\neq$ 广百

合》、2分

三溶紧れ-

數菌便 $5=$

回及雜菌

反ビ菌ヨ八

復凝, 證温

シ集多明室

テ区数七三

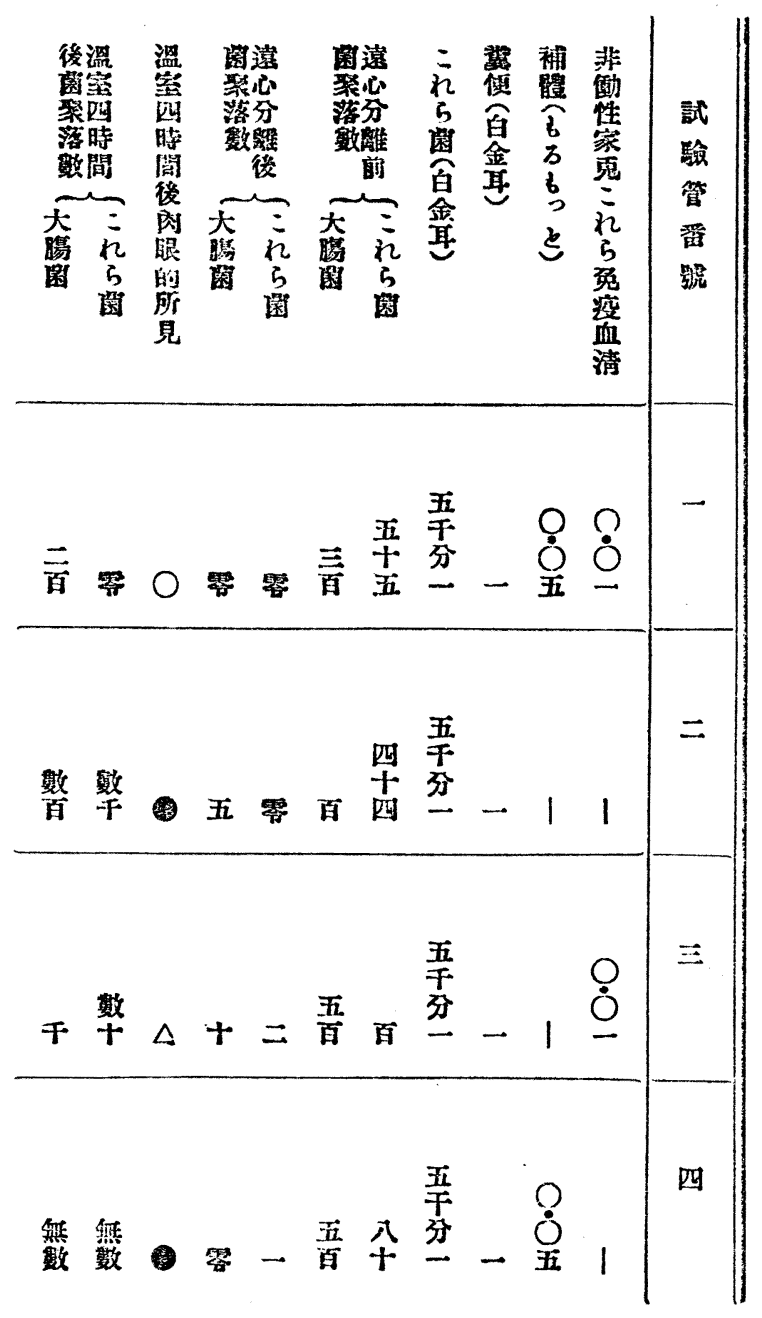

得礁鼬 ズ 時

夕 7 在第 間

ル呈セ三㳇

結スル管 主

果 $ル=八 下$.

正拘㻄分

舉, 集 一

グナラ反

ベリズ應テ 
( 27 )

\begin{tabular}{lll} 
琎 藏 谷 $\quad$ 辻 \\
\hline
\end{tabular}

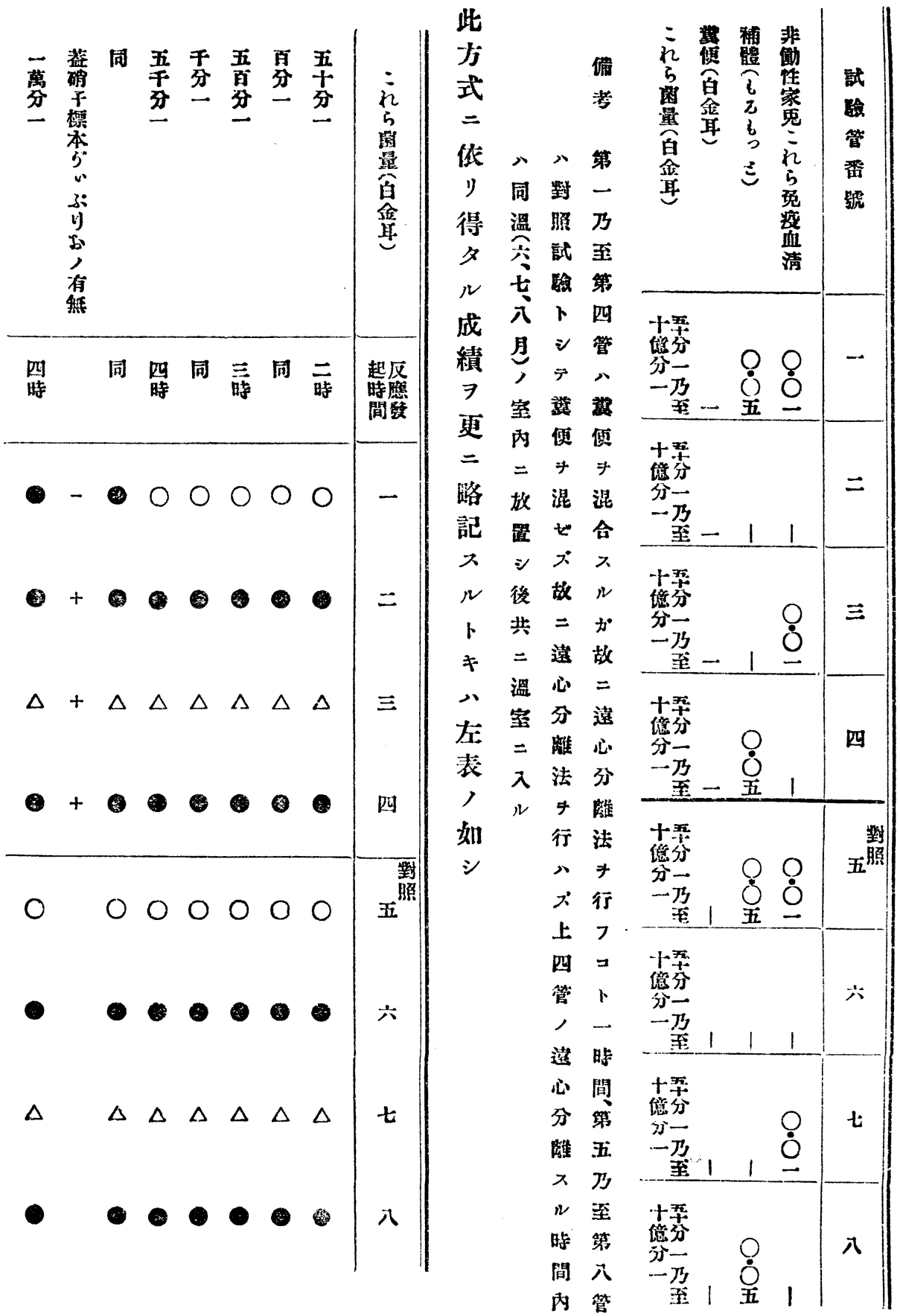




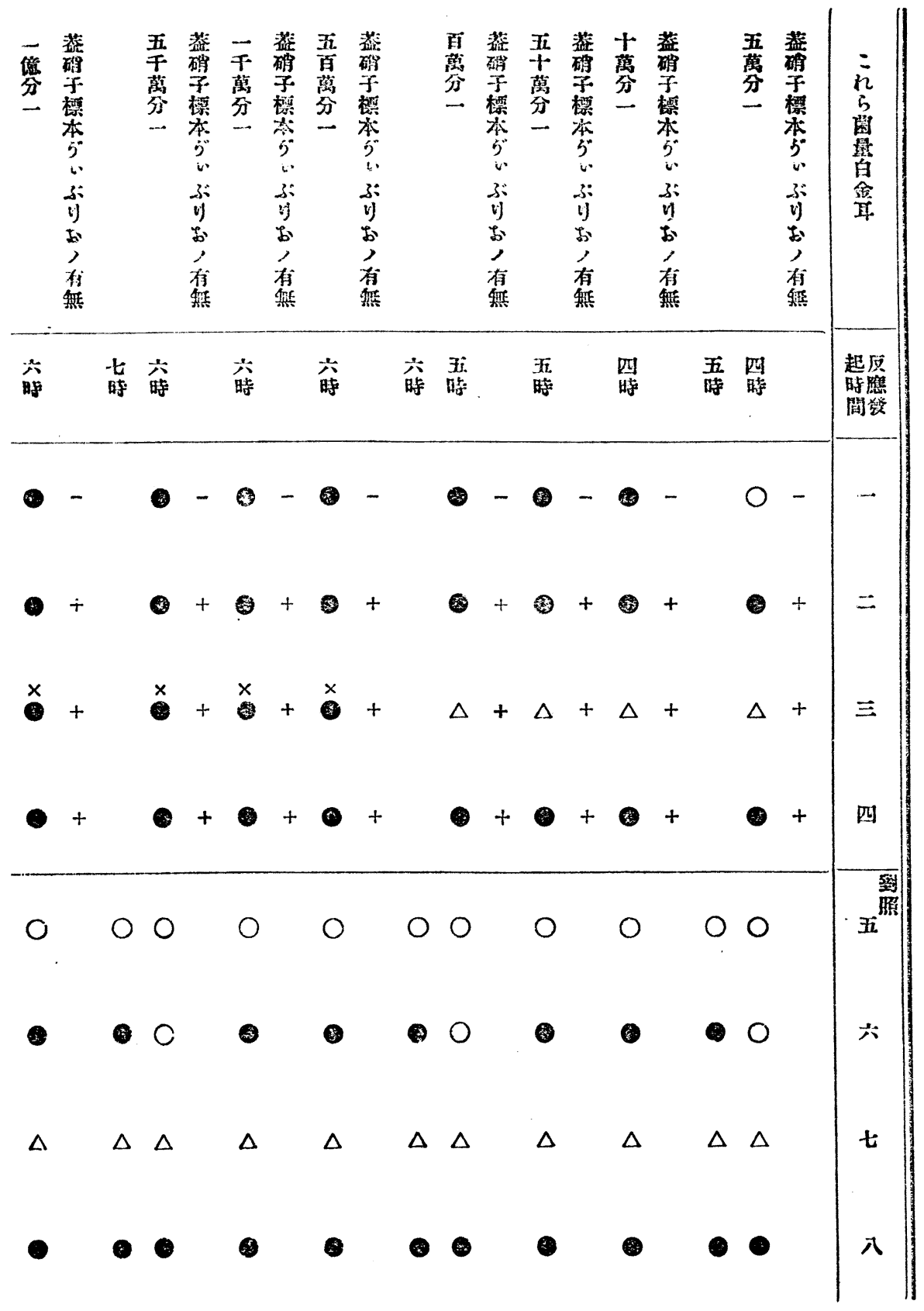


(29)

迅

滆

幾

谷

计

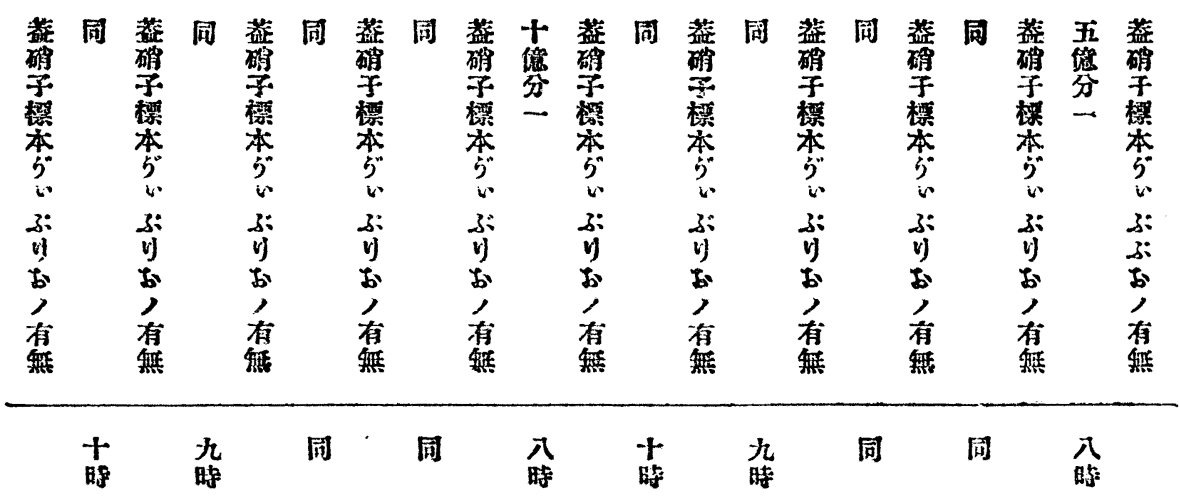

- $-0-0-0-0-0-$

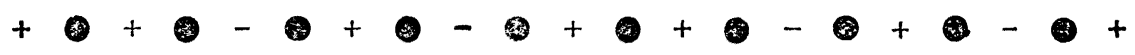

$+0+2+\frac{x}{0}-0+0+2-0+$

$+2+0+0+0+0+10+$

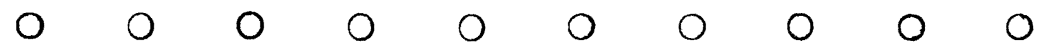

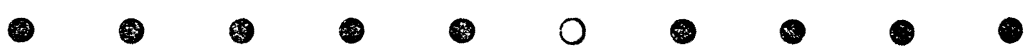

$\Delta \quad \Delta \quad \Delta \quad \Delta \quad \Delta \quad \Delta \quad \Delta \quad \Delta \quad \Delta \quad \Delta$

- 100100 


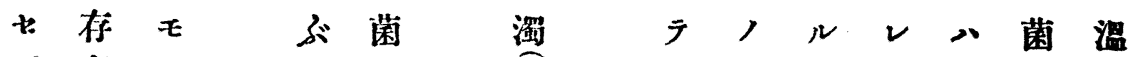

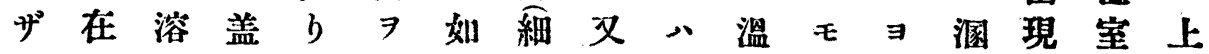

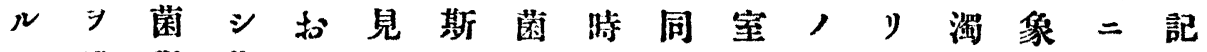
ガ證現茲, 几第性卜時 故 明 異二存, - = シ 間入ע下主

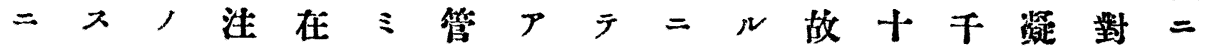
白心行意 $\ni$ 二溷 金シ八大證 シ 滔 ズ便 $テ 卜 2$ 分一反試

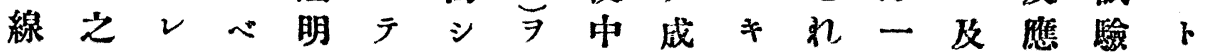

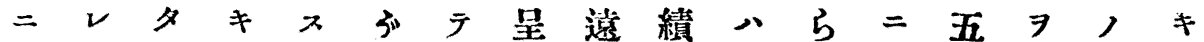
付乙N八ル肉少何既菌至萬認純

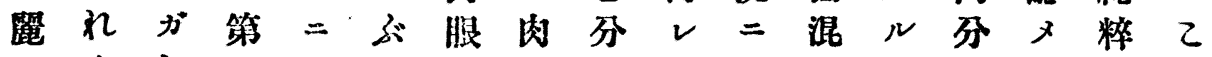
シ 5 如三依 り 的眼踓 $モ$ 肉和 $\checkmark$ 一得培れ

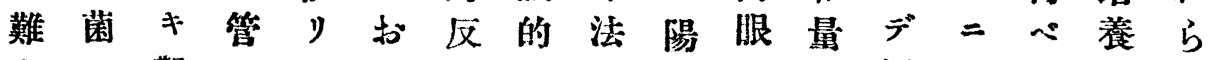
キ 八觀, 溶 八庥二 二發 7 蓝菌存不反行ナ溶萬涪第然ミ量 因生呈硝現在明應七り菌分り一

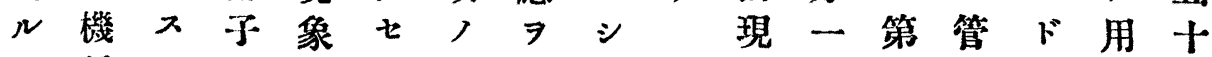

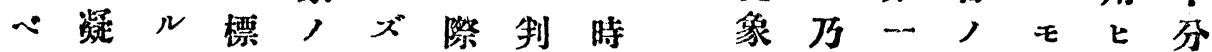
シ集 コ本發之八定上 奬

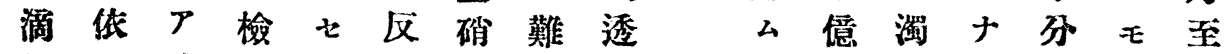

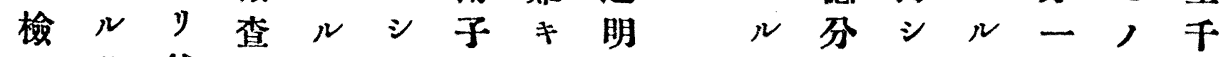

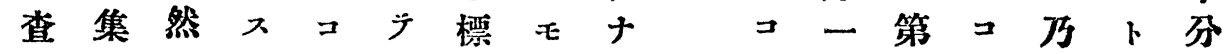
法團レルト第本, ル白三卜至同一

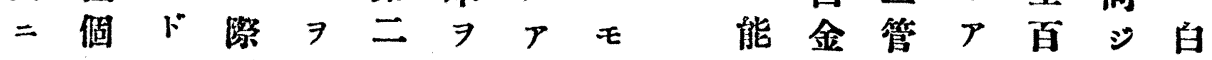

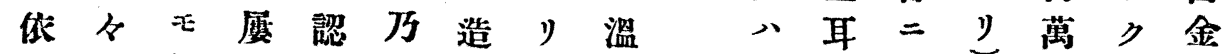
儿相仔々知至り 室 モ分細 亦踓 $=\cdots$ 得四检四擬管白至混 タシ 檢 ぶミ管 ス ル 反時集二金三 シ

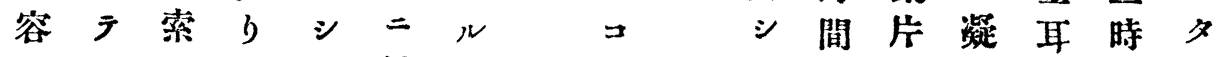

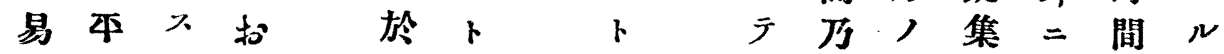
二等ル $ル キ$ 二 對至存反在二モ

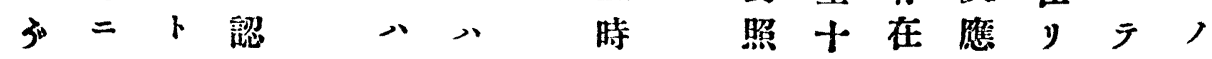
、液 $\neq$ × 何只間試時

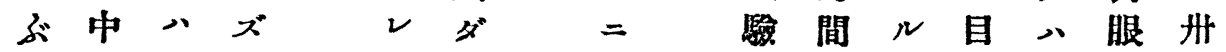

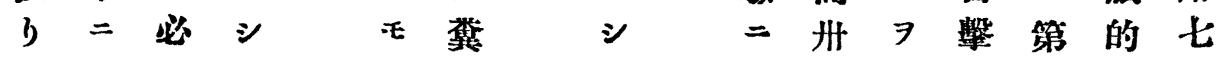
お。混 ズ う便 テ 在七認 和其恰以雑溷り度么之管溶, 
和 四一

乙中 時

濁れ金

れ, 間來第菌二=

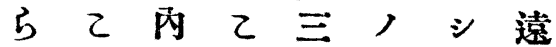

菌れ外风管繁 $テ$ 心

量 $5=5$ 殖温分

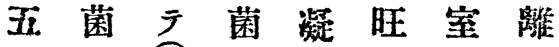

千磉主八集盛時 法

分青十試区ナ間

一 シ 七器憵ル 八行

白テ度管.

金溷溶內呈篇時肉

耳濁菌二スメ間眼

以 7 ス於儿第十的

下是べテナーリ容

ナスシ 基り管卜易

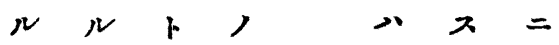

$卜=$ 踓能元 即溶

キ至 ド 铨

八リ E 性

其初命免

成 メ ガ 疫

啨 广方血

）肉法清

知 眼二 =

心的從依

二制

四定 ※テ

時 7 他 動

間下，物

以 シ 對 體

上 得 照 内

ヨ心試二

質キ驗於

サガ管分

ザ故第ル

$N=$ 二

ベ若乃同

カ: シ 至 シ

三混第 ク
トチ菌

溶 此 現

菌 時 舜

ス 間 7

ル丙制

$==$ 定

低 テ シ

リ 八得

透蕉 心

明便 $キ$

二申境

it, 界

$\checkmark$ 放

ル 菌 混

モ多和

第少菌

二發 量

第 督 -

四 万下

管 几 分

$\therefore モ-$

溷乙百
ス害レ應

七现 72 的

單 7 右

ララ呈れペメ上

ルクスら ぷズ表 检

N $\cdots$ 菌 $\varepsilon$ 反二定

二混二混ん\%於

化和拘和水 $\bar{~}$ 得

ル2八量 $\exists$ 對明心

べ无り照ナシ

シらズ億モ第ル

故菌谷分蕉三如

二量管一便管 ク

如, 溷乃 7 兵偗

斯極濁至混; 便

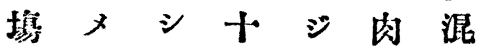

合テテ億タ眼合

二少蓝芀儿的,

八數硝一モ溷 モ

他ナ子白, 濁,

例ル標金

$=$ 二本耳營呈否

於区二=唯入习

テシ何テ并ルザ

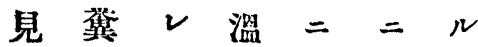

ル便モ室富倘モ

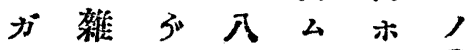

妇菌 $い$ 時 $カ 5$ 一對

クノぶ 間 故 時 照

佮铣りノナ間下

栘多打

湓ナ

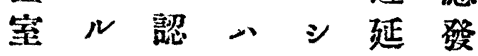

中ガ 對 入起

二篇ザ照 ル 時

留メル試間

置 其 $モ$ 噞, =

ス發ノ八更

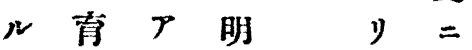

フノリ 二 之差

要 妨之反 


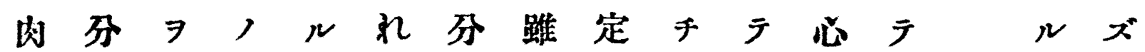

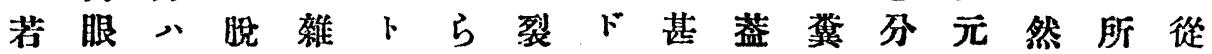

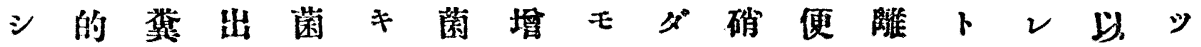

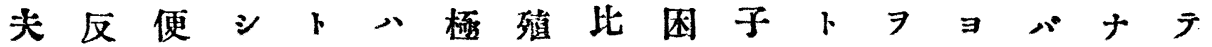

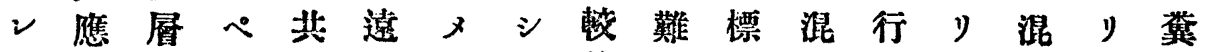

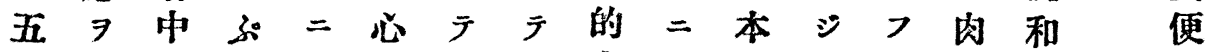
境呈二民試分少䧴多

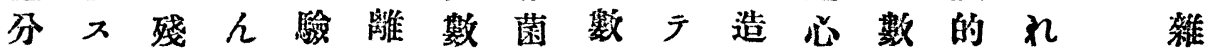
一儿留水管法人二ノ時り分卜制ら菌 万所 至以之 二

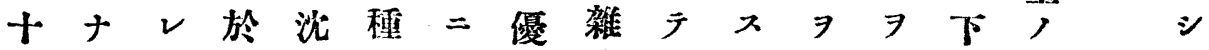

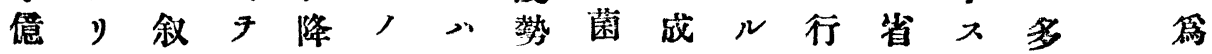

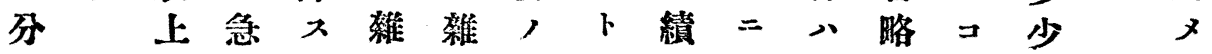
一, 速卜菌菌位其, 一 ス シ ト = 白刘力踓抑, 置二不般 シ 得能拘第

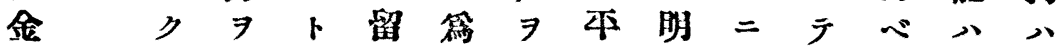
耳 對 以 モ法

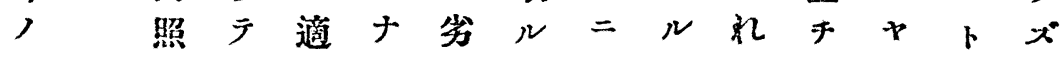
如試繁温り敗ニペコら=否踓初 $\eta$ 䛗 殖

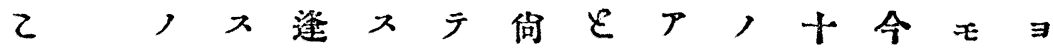
れ純ル人即㝽ホんり墢七上蓝り 万粹 二 バ $千$ 二多水之育度記确直 菌培区活此發乃中レ, 八方子チ 僅養 シ 潑法青, = 乙不溫式標二

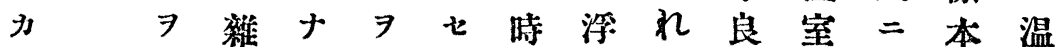
二 用菌 $ル$ 行 ザ間遊 ら

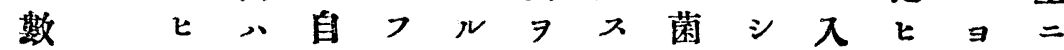

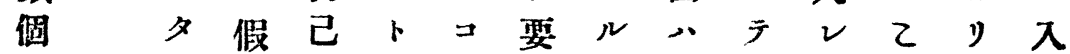

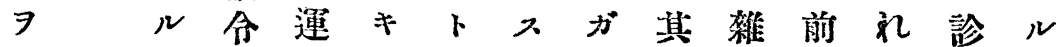

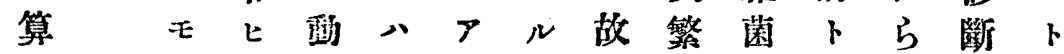
ス, 增力 $力 y=$ 二殖多同菌济 ルト殖二れ此因其甚数時 7 得八 ガ同ス化 万點ス墢ジナ間種べ各

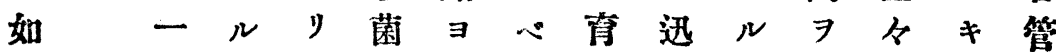
キ 時 モ $テ$ 八リシ妨速 ガ經ノガ八

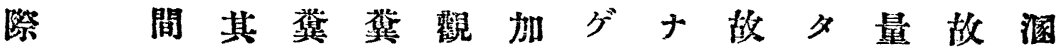
二内大便便察之ラリ

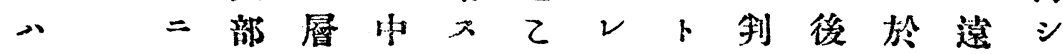


(33)

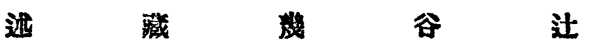

曹》强失五堂亞 八常

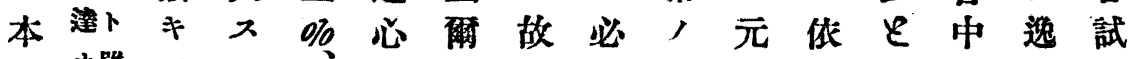

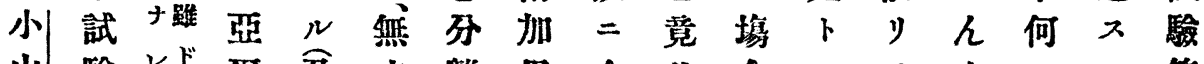
山驗 レド爾鬼水踓里余此合 2 水レル管 菌 =

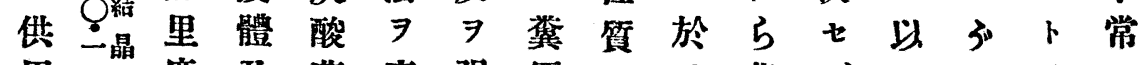

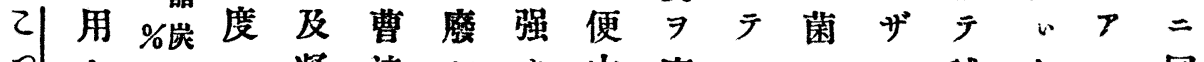
つ七二酸”凝蓱シ”中應入八ル試ぶル同

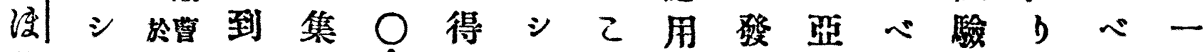

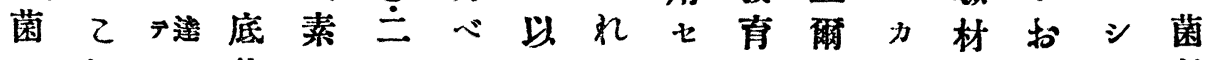
行明㑊入 $\%$ 万

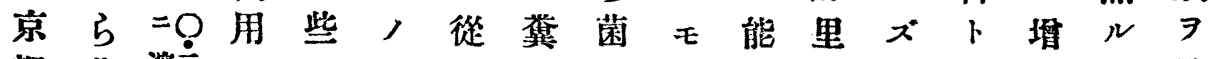

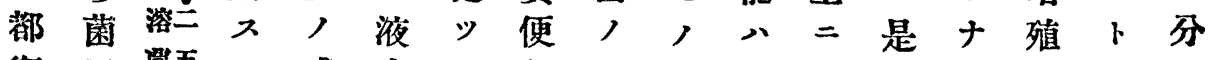

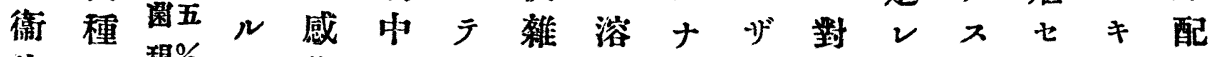
生 八現\%

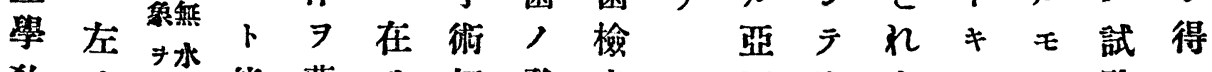
教, 呈虑能蒙り極發查爾比ら八, 驗ル 室如酸 八ララメ有法加較菌各 $\exists$ 成モ 菌シ 解芯甘テ

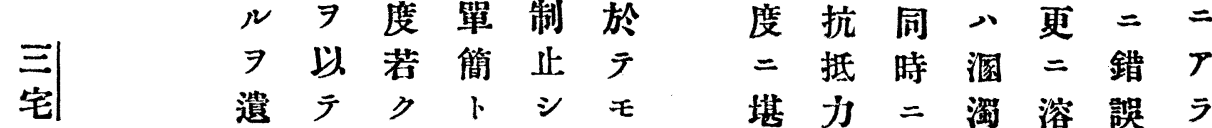
菌 喊 霬八ナ主 亦 堪 力 二 溜 溶 誤 尾占便 井 余雜度 シ テ 理 二强顀 シ 菌 $\ni$ ズ ルク便厅試 來 時 特培 雜肉羷 ス下 性萯菌腿 $\exists+$ シ

菌

井

菌

吉
川

菌

吉|

菌
乐菌 $=12=$ 龦, 於踓れ訨 二三發 テドらり $\% \bigcirc$ 青一 $モ$ 菌 培 冯 7 時補 7 養 ヘ\% 制 間體繁，液 3) 此: 後八殖, 只結入既結七營 儿晶ルこ晶シ冨 水宸 酸瞥足作酸 ル 用造 $几$ 用曹 讲晌 7 達 $\neq$ 加 加木消 ○一
$\Rightarrow$ 基 $\Rightarrow$ 的 反勿 有中混二復諭或 ス營ズ鑑七ナ試 所瀁儿別ザリ驗 謂 分 ガ $ン$ 故管 2, 故難 べ= = れ增ナシ少如於 ら加》必 $ラ$ 斯 菌 ス ズ ズ境 特 選 = 硝 $三=2$ 培從子堦八れ 差 七 检菌試 ら 基通查ぺ䠯菌 


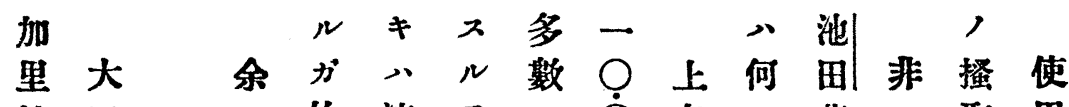

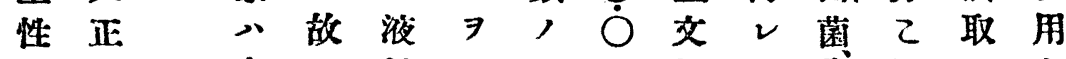

反三患二量以惯卜既 $モ$ 內i れ二白

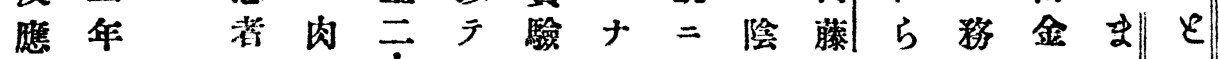

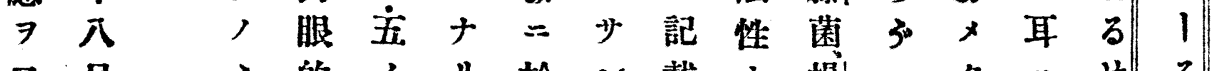

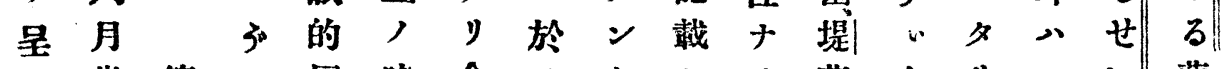

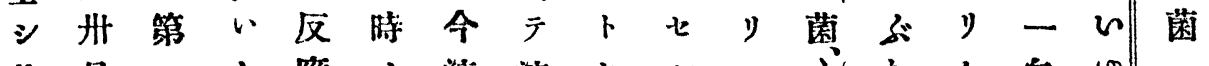

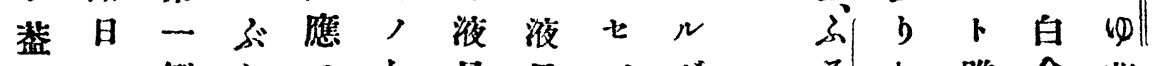

确 2 例 57 如量量

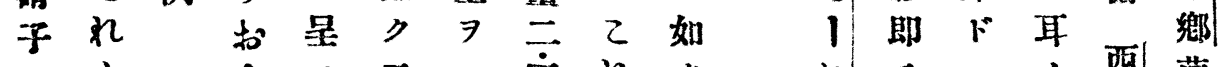

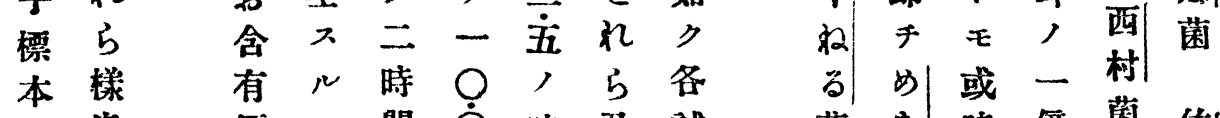
二怒 便 = 間 $\dot{O}$ 時免 試 于晢 $\exists$ 、

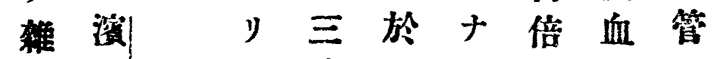
菌田武時テシ人, 清, 中吉驗間溶之绝及液 乙本セ 7 菌レ没ビ量 ん, ル烈現二血補

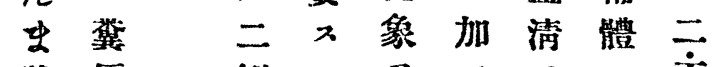
弉便例 7 フ 第 $7 \quad \exists \quad$ 認 , 检有么處へ量り 样查入N, 在 2 其 $=2 N$ 八 $\exists N$ 成。占电四

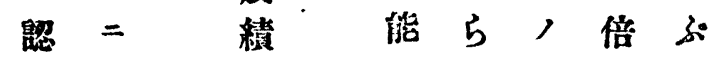
么带左八菌爿量 黄ノ ズ量モ下ん

線如是五完十水 色 的等少 流四分ナげ添

動倍一N 架

性

二白溶へシ

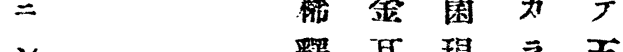




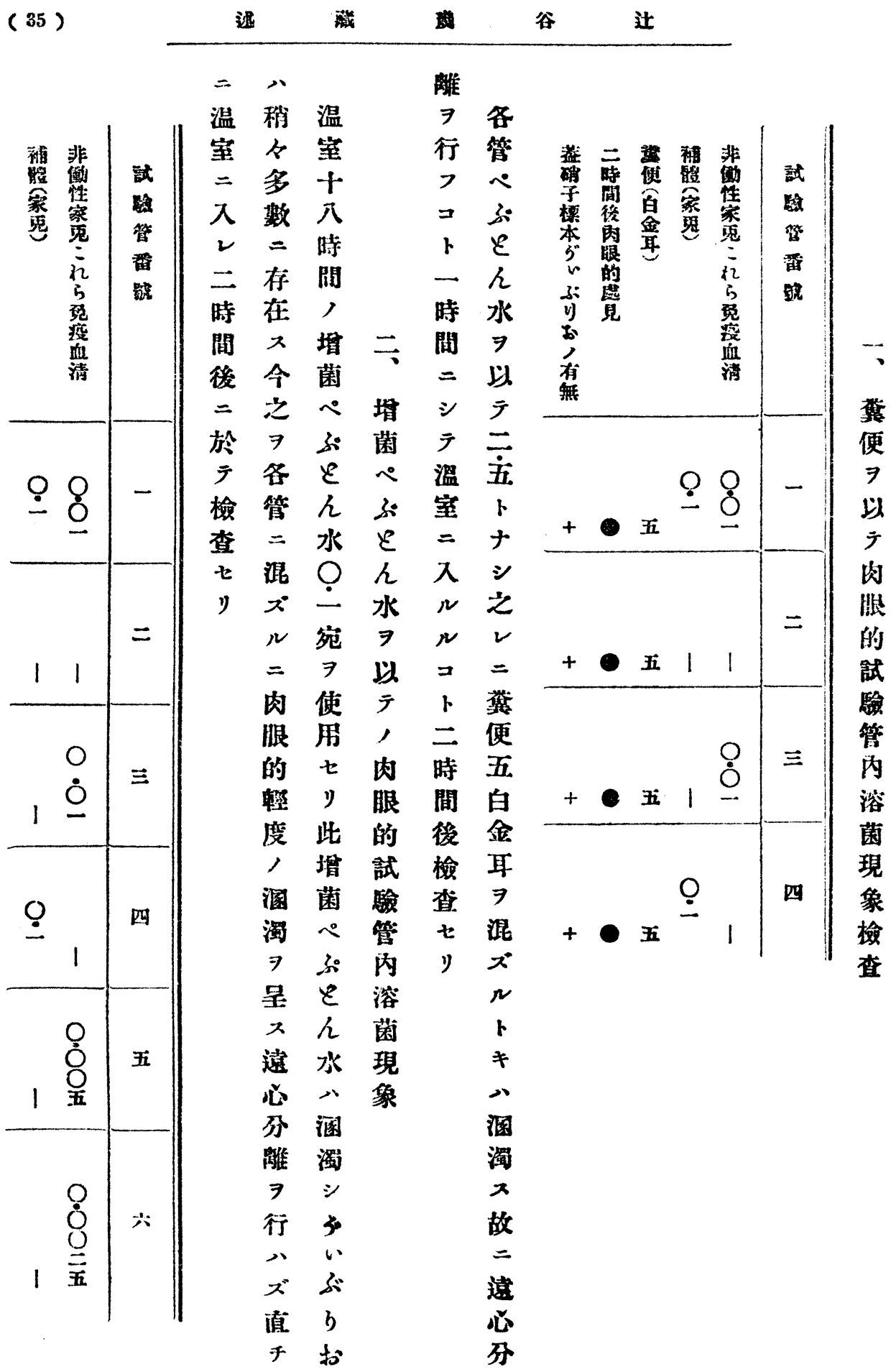




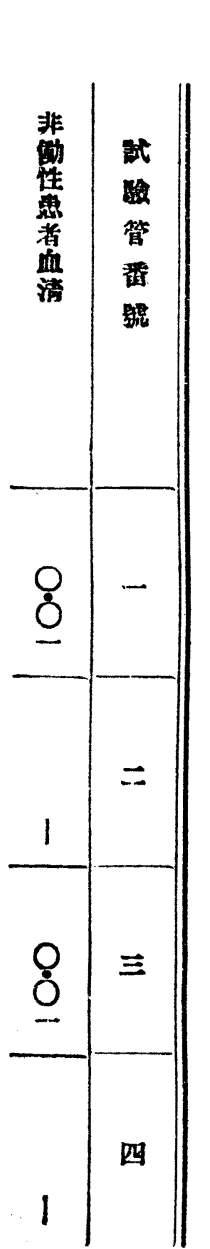

$+$

倍九

百 倍

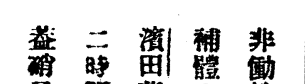

$=$ 三

於

于 發

㕠䇰管四

反二

應 $\exists$ 患

ᄏリ者

呈患 血

七者 清

ズ嶈 7

液以

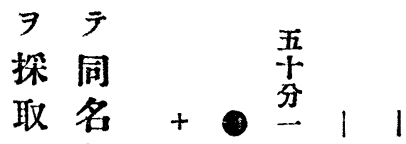

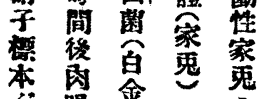

\begin{tabular}{l|} 
試 \\
硯 \\
管 \\
番 \\
㴲
\end{tabular}

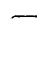

尔眼每

范㹂

鬼

n

否

無

篮

シ 菌

$\bar{\gamma}=$

检

查

Ł $N$

少肉

本腿

清試

八䝂

渭| 管

时丙

菌 浴

二 菌

對 現

シ 解

二 检

十查

五,

倍

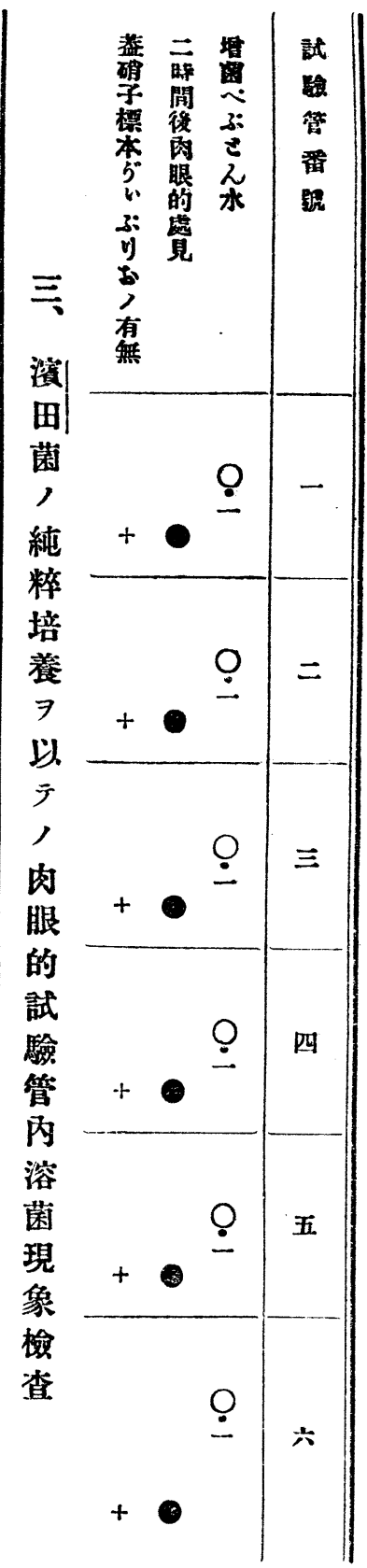

王. 


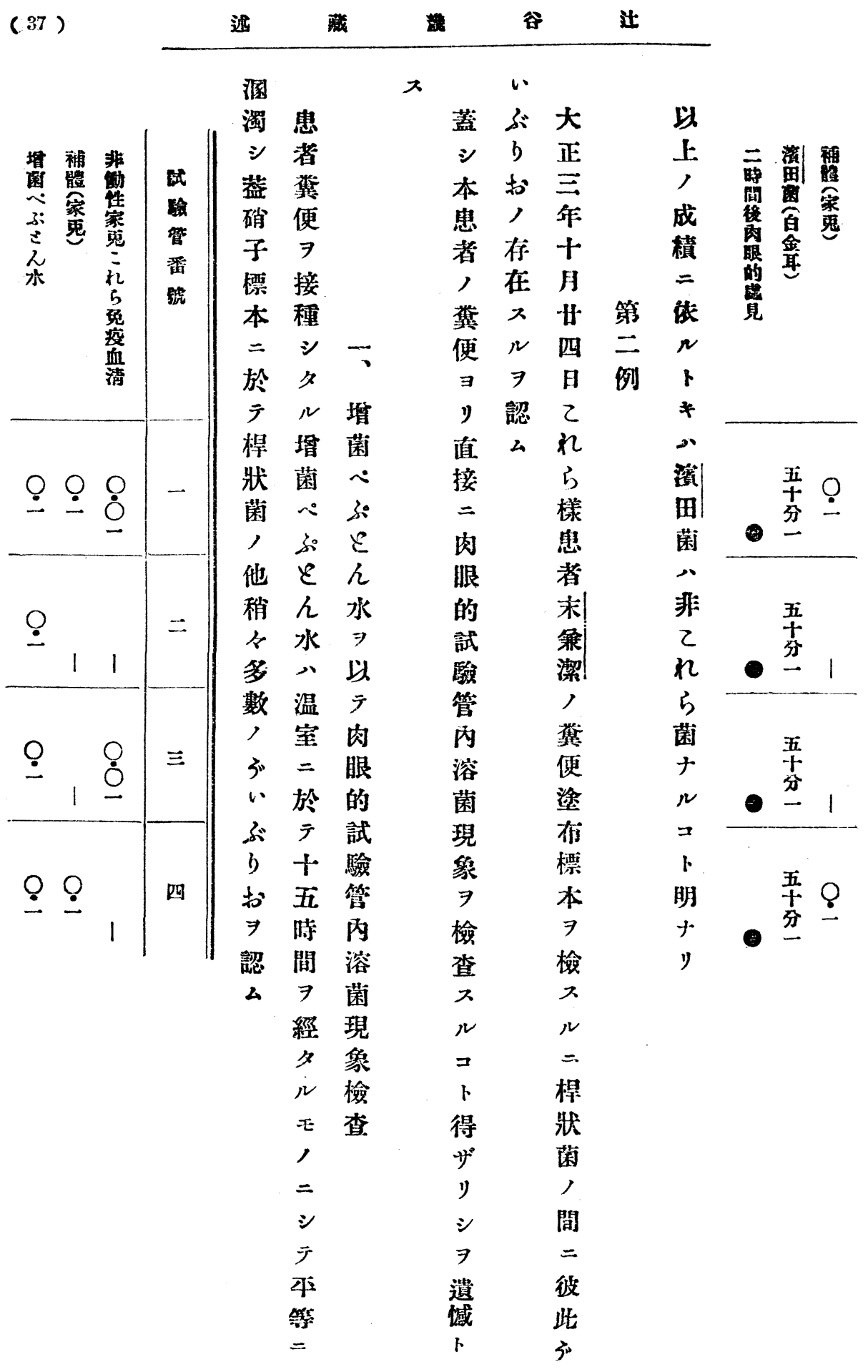




\section{ナシ，微 润}

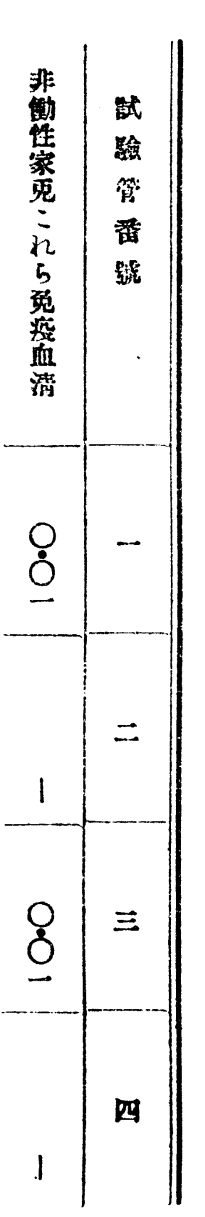

第本り上第少細 ス全 成記三教, 直量 鈢 成管 7 凝 綪 二見管 $=$ 主. 確、, 管 本處, 有室此 息々 $\&:=$ 例 三 著 $=$ 第入 、萑於 シ 三レナ 純卜便テテ管四シ 粹 7 中 3030 , 時夕 培保 こいい著間 飱障混ぶぶ明後各 $\exists$ 七 在 $b$ b 以 $ン$ 七㧤凝 $7=$

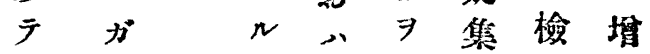
，篇潗哂入入菌 肉丈團丈ルルぇ 腿 佾 ぶ $\exists$ ズ $7=3$

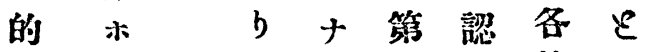
武次吉 シ三么管 ん 巸, 八, 第蓋溷水 管試正著四硝滥 ○ 內擥二色管子， 溶 $\Rightarrow 2$ 七 摽度宛 菌行我本 $\exists \rightarrow$ 現 万只 7 y八增加 象り菌認亏第 シ フ 检艺么》一第ル 查

\begin{tabular}{|c|c|c|c|}
\hline 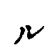 & 多 & 管 & 一 \\
\hline$\exists$ & 數 & $=$ & 第 \\
\hline r & ' & 於 & 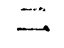 \\
\hline$\exists$ & 3 & テ & 第 \\
\hline as & $w$ & $\therefore$ & 四 \\
\hline 朋 & ぶ & 只 & 管 \\
\hline ス & $b$ & 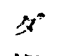 & त \\
\hline 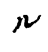 & お & 棏 & 極 \\
\hline & 存 & 㰾 & メ \\
\hline & 在 & 菌 & \\
\hline
\end{tabular}

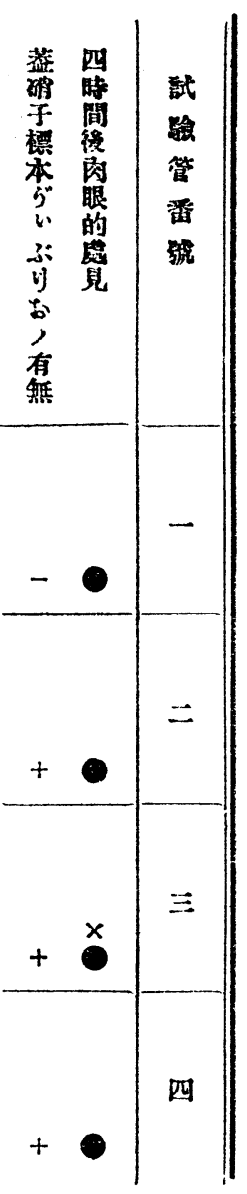




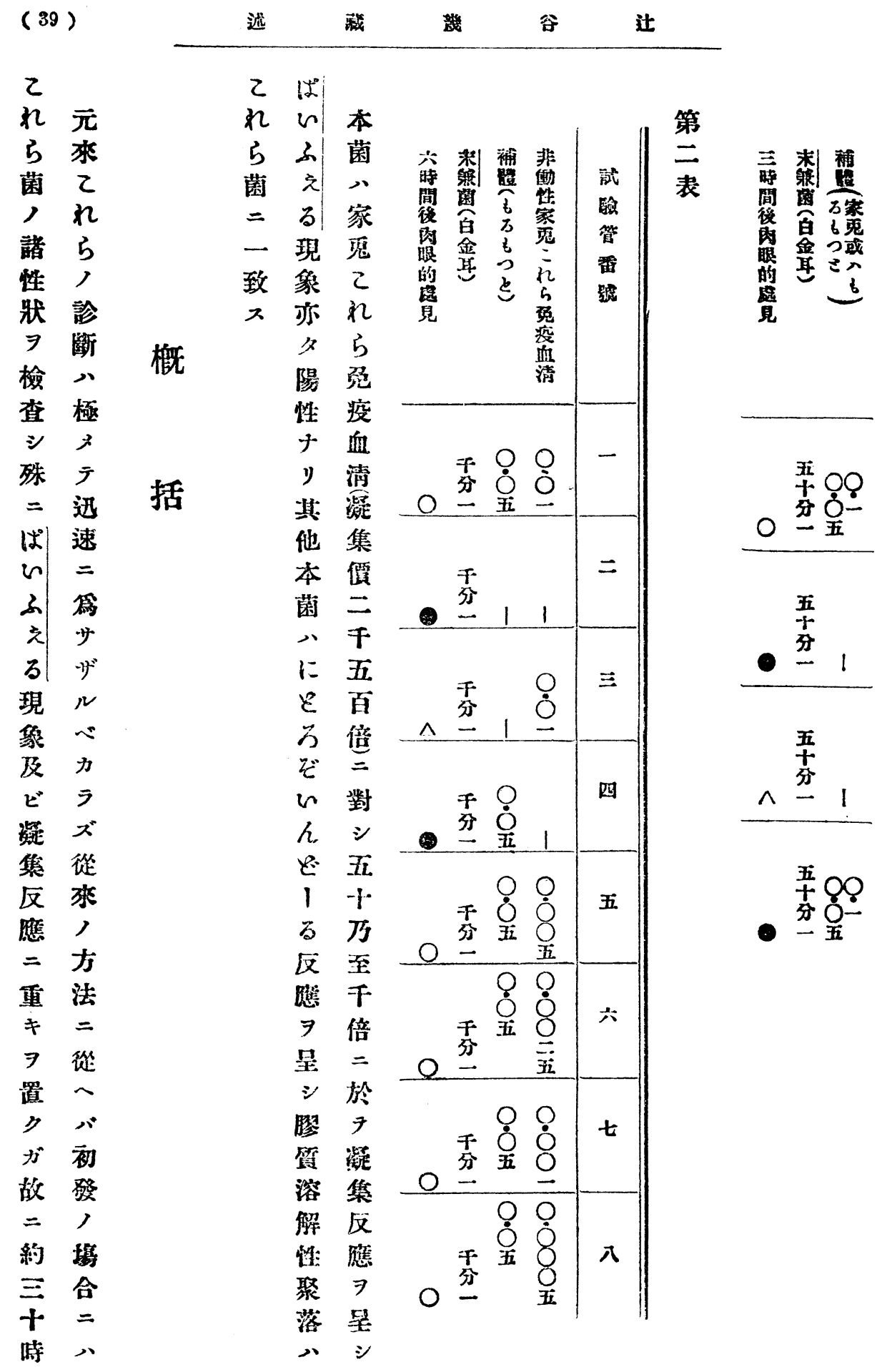


二者乃 $\neq r=2$ 定 7 間 於, 至八共結れ規 27

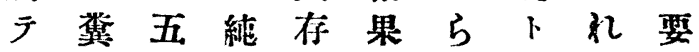
存便時粹 ス 7 菌 ス 在八間培 $几$ 知聚然菌續 ス乙甚餘モ了落ルト發

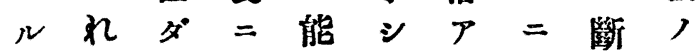

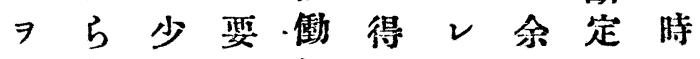
以菌キス性べバガシ八 テ携卜ル乙 シ 優方通發

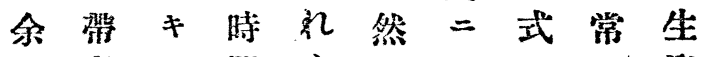
ガ 者 分輕踓 7 免份菌依的落 式症下短疫䅐儿方= 二者モ縮血進象卜之就 從 7 七 清 ン 几除時得 心゙キ間心依本集純像滴 極所肪シリ試反粹陚檢

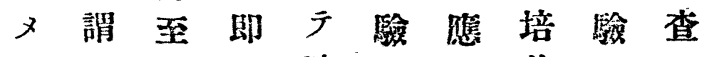
テ米十天溶成 7 養 $\Rightarrow=$ 短浛一殊娟綪二于缺 $\exists$ 時汁時二ス, 時 $レ$ 如》 間樣間便ル示間 ゙ ス凝 内二後中 $カ$ 内後前儿集 $=シ=2$ 故 $\pi^{\circ}=$ 報

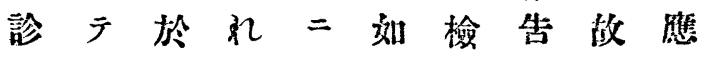
然 $\bar{y}$ 然直》定 $==7$ シ $モ$ 决第 $千 2$ 之於二檢 得 2 定, $=$ れ得 $\bar{日}$ 心れシ含 $2 ら ル$ 記時成 シ 万得量れ菌 $\Rightarrow$ 载間績 菌べ多ら八以七以陽

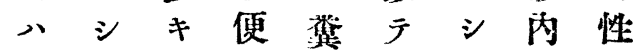
純况卜 粹ヤ丰健中十如决儿 培 2 八, 用, 時》定卜 篦れ三入諸間一入

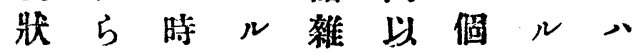

態患間 $⺊$ 菌內, 